\title{
Abundance and Factors Affecting Population Characteristics of Waders (Charadriiformes) in Great Vedaranyam Swamp of Point Calimere Wildlife Sanctuary, South-east Coast of India
}

\author{
R. Manikannan ${ }^{1}$, S. Asokan ${ }^{1}$, A. Mohamed Samsoor Ali ${ }^{2, *}$ \\ ${ }^{1}$ Department of Zoology and Wildlife Biology, A.V.C. College (Autonomous), Mannampandal, Mayiladuthurai, \\ Tamil Nadu, 609305, India \\ ${ }^{2}$ Division of Environmental Impact Assessment, Salim Ali Centre for Ornithology and Natural History (SACON), Anaikatty, \\ Coimbatore, Tamil Nadu, 641108, India
}

\begin{abstract}
The abundance and factors affecting the population characteristics of waders in Great Vedaranyam Swamp was studied during 2007-2010. This wetland is a Ramsar site and an Important Bird Area. This habitat attracted 30 wader species, which are local and migratory bird species. Highest population of Greater Flamingo Phoenicopterus ruber was recorded in all the years of study period. The physico-chemical parameters such as calcium, chloride, dissolved oxygen, electrical conductivity, magnesium, nitrate, nitrite, $\mathrm{pH}$, phosphate, total dissolved solids, salinity, sulphate, turbidity, water depth and water temperature have been tested. The physico-chemical parameters were compared with the small and large waders density (birds $/ \mathrm{km}^{2}$ ) and diversity $\left(\mathrm{H}^{\prime}\right)$. The multiple regression models were made to evaluate the relationship between the physico-chemical parameters and waders population characteristics. Such a water quality parameters showed significant variations among the variables. The abundance of phyto and zooplankton, polycheates, gastropods and decapods, the prey items of the bird were also compared with water quality parameters that showed significant variations. The result suggests that physico-chemical parameters of water as a vital role to regulate the bird community and their prey items.
\end{abstract}

Keywords GVS, Density, Diversity, Physico-Chemical Parameters, Prey, Waders

\section{Introduction}

Waterbirds comprise a large group of species including Anseriformes, Charadriiformes, Ciconiiformes, Gaviiformes, Gruiformes, Pelecaniformes, Podicipediformes and Procellariformes. Charadriiformes is a diverse order of small to medium-large birds. Wetland supports congregation of large number of migratory and resident bird species as it has high nutritional value as well as productivity[1]. The bird distributions are affected by various factors like the food availability, the size of wetland[1] and the abiotic factors in the wetlands[2,3]. The importance of abiotic factors has long been recognized in the habitat preference of birds by many authors[4,5], only recently have investigators concentrated on finding out how particular abiotic factors affect waterbirds[6,7]. The water quality is important in waterbird habitat assessment because a host of interacting physical and

* Corresponding author:

amsamsoor@yahoo.co.in (A. Mohamed Samsoor Ali)

Published online at http://journal.sapub.org/ije

Copyright (C) 2012 Scientific \& Academic Publishing. All Rights Reserved chemical factors can influence the level of primary productivity in aquatic ecosystems and thus influence total biomass throughout the aquatic food web[8]. Indeed a relationship between water quality and waterbirds had already been indicated by several studies $[5,9]$. It has been inferred that the physico-chemical characteristics of the water largely determine the waterbird community of wetland habitats, primarily by their direct and indirect impact on the availability and abundance of the birds' prey[6]. Waterbirds acquire important nutrients by feeding on benthic fauna and plankton the availability of which is influenced by physico-chemical variables. Benthic invertebrates have been found to be the primary foods of waterbirds[10], and these invertebrates have also been found to strongly influence the distribution and feeding behaviour of waterbirds[11]. In this paper, we assess the abundance and factors affecting the density and diversity of waders (Charadriiformes) across the years between 2007 and 2010 in the Great Vedaranyam Swamp (GVS) of the Point Calimere Wildlife Sanctuary.

\section{Study Area}




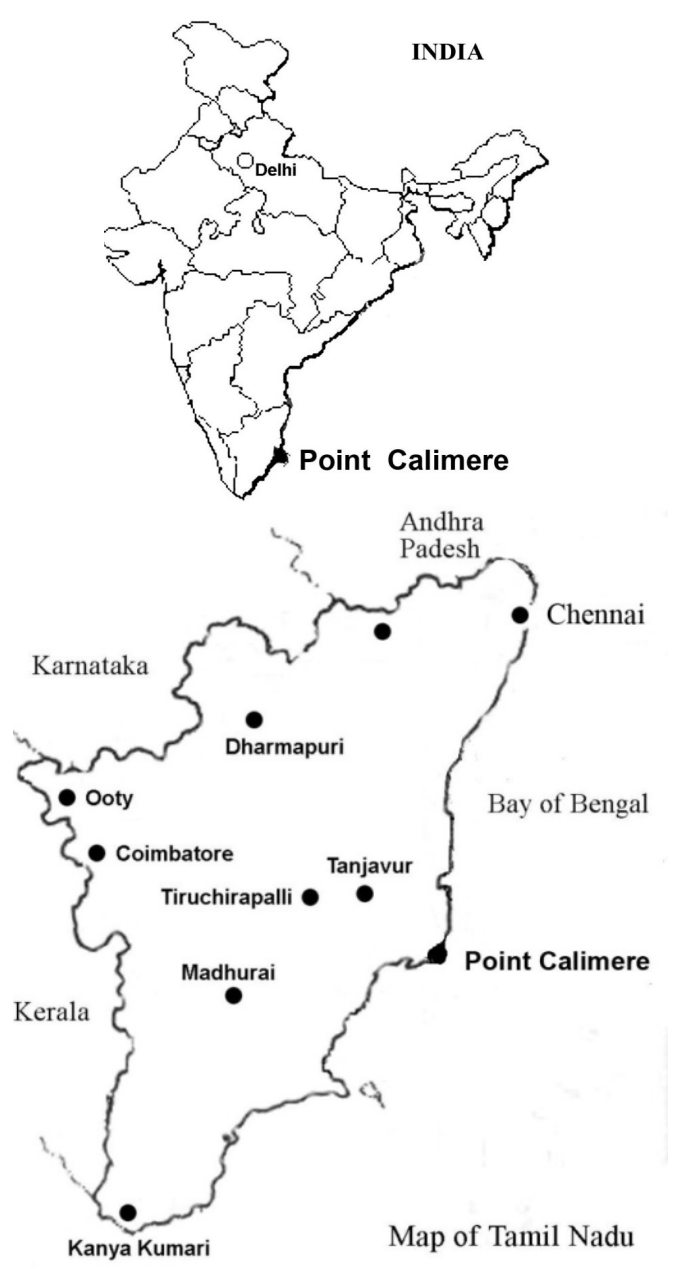

Figure 1. Map of India and Tamil Nadu showing study area

The GVS of the Point Calimere $\left(10^{\circ} 18^{\prime} \mathrm{N}, 79^{\circ} 51^{\prime} \mathrm{E}\right)$ is situated in the state of Tamil Nadu in Nagapattinam district (Figure 1). The GVS stretches for about $48 \mathrm{~km}$ from east to west, parallel to Palk Strait separated from it by a sand-bank. There is a gradual north-south slope. Five fresh water channels empty into this part of the swamp. The swamp contains water only during the monsoon, which gradually dried up in the summer and converted in to small pool of water. The entire swamp belt is about $30 \mathrm{~km}$ long and $9 \mathrm{~km}$ wide. It is screened from the Bay of Bengal and Palk Strait by narrow strips of sand banks with many openings. The most important openings to the sea from the swamp are "Manavaykal" and "Sellakkani" mouths. Seawater enters to the eastern half of the swamp mostly through these openings. This swamp represents a mixed ecosystem, influenced by both fresh water and seawater. Two industrial salt companies Chemplast (Chemical and Plastics Limited), DCW (Dharangadhra Chemical Works) and a number of small and large salt units that produce edible salt and industrial salt operate in this area. The climate of the area although classified as monsoonal, but it is not typical of monsoonal climates due to its asymmetrical rainfall regimes. The main contribution to the rainfalls is from the north-east monsoon (October-December) and the average rainfall ranges from $1000-1500 \mathrm{~mm}$. The highest temperature $\left(34^{\circ} \mathrm{C}\right)$ is recorded in May and the lowest $\left(25^{\circ} \mathrm{C}\right)$ in March and April. Relative humidity remains high throughout the year due to coastal influence. Strong winds are prevalent during certain months, especially in June and July. Point Calimere Wildlife Sanctuary was declared as a Ramsar site on $19^{\text {th }}$ August 2002.

\section{Methodology}

Data were collected from October 2007 to March 2010 which included four seasons viz., Post-monsoon (January-March), Summer (April-July), Pre-monsoon (AugustSeptember), and Monsoon (October- December).

The waders' abundance was estimated by direct count method (in three different stations) as described by Nagarajan and Thiyagesan[6]. Observations were made twice a month in the early morning and late evening during the study period. The waders were observed through a 7'x50" field binoculars and a $30 \times 60$ telescope. The birds were identified on their characteristic features by following Ali[12], King et al.[13], Sonobe and Usui[14] and Grimmett et al.[15]. The density (birds $/ \mathrm{km}^{2}$ ) and diversity (Shannon Weiner index) of waders was calculated.

Statistical analyses were performed by using window based statistical package Minitab (version 13.1). The effect of physico-chemical properties water and prey availability on the density and diversity of small and large waders were investigated using multiple regression equation models. The waders density and diversity was regressed against physico-chemical properties water and prey availability in iterative stepwise multiple regression. We developed regression models using both step-up and step-down procedures.

\section{Results}

Given below are the accounts of 30 wader species (11 large and 19 small waders) recorded from the GVS of the Point Calimere Wildlife Sanctuary.

\section{Little Egret Egretta garzetta}

This species was seen quite commonly throughout the year, usually forages in shallow to relatively deep water in association with other birds. A maximum count of 63 (during January 2008), 41 (during January 2009) and 34 (during December 2009) individuals were recorded at stations I, II and III respectively during the study period.

\section{Western Reef-Egret Egretta gularis}

This species was seen occasionally in the study area. The highest count obtained during this study was 3 birds off station I during November 2008, 4 birds off station II during January 2008 and 11 birds off station III during December 2009.

\section{Grey Heron Ardea cinerea}

This species was recorded occasionally throughout the year except June, July, August and September. In stations I, II and III maximum count of 22 (January 2008), 7 (January 
2009) and 8 individuals (December 2009) was observed.

\section{Large Egret Casmerodius albus}

This species is locally very common in the Point Calimere it was seen in all months during the study period. Though they are colonial but hunt solitary, standing in shallow water with neck outstretched and held slightly forward for prey to come within sight. A maximum count of 59 (January 2009), 47 (January 2008) and 31 individuals (December 2009) were recorded at stations I, II and III respectively.

\section{Median Egret Mesophoyx intermedia}

This species is usually found throughout year except June, July, August and September. It is more social than other egrets. During the study period, a maximum count of 24 (January 2008), 13 (January 2009) and 17 individuals (December 2009) was recorded at stations I, II and III respectively.

\section{Indian Pond-Heron Ardeola grayii}

This species was seen quite commonly throughout the year, usually single and foraging mostly at the edges of water bodies. In station I, a maximum count of 11 birds was recorded during January 2010, in station II, 6 birds were recorded during January 2009 and station III, 6 birds was recorded during December 2008.

\section{Painted Stork Mycteria leucocephala}

This species is locally very common in the study area and it was seen in all months. The highest count of 94 birds was obtained during January 2009 at station I, 88 birds during January 2008 at station II and 42 birds at station III during January 2010.

\section{Eurasian Spoonbill Platalea leucorodia}

This species was recorded occasionally with small numbers, with the largest flocks of 21 birds recorded during December 2007 at station II and 18 birds during January 2009 at station I and 14 birds during December 2008 at station III.

\section{Black-Headed Ibis Threskiornis melanocephalus}

It is very rarely seen in the Point Calimere and maximum number of birds observed during this study was 4 (January 2009) in station I and III (November 2009) and no birds were recorded at station II.

\section{Greater Flamingo Phoenicopterus ruber}

This species is very common seasonal migrant in the Point Calimere Wildlife Sanctuary and it seen large congregation during monsoon season, but some birds can be found almost throughout the year. The maximum numbers counted during this study was 1,254 (during December 2009) in station I, 841 (during January 2010) in station II and 569 (during December 2008) in station III.

\section{Lesser Flamingo Phoenicopterus minor}

It is rare seasonal migrant species found only December and January. The highest count at station I was 117 birds in January 2009, at station II was 63 birds in January 2010 and no birds were seen at station III.

\section{Grey Plover Pluvialis squatarola}

The Grey Plover was very rarely recorded in Point Calimere Wildlife Sanctuary with a few sightings of solitary birds or a party of a few birds from November till February. The high counts include 5 birds in January 2009 at station I, 4 birds in January 2009 at stations II and III.

\section{Common Ringed Plover Charadrius hiaticula}

This is a rare species and was mostly recorded during January. A high count of 8 birds was sighted at station I during January 2009 and 5 birds were sighted at stations II and III during January 2009 and December 2008 respectively.

\section{Little Ringed Plover Charadrius dubius}

This is a common seasonal migratory species to the study area. The highest count of 36 birds was recorded at station I in January 2008, 29 birds at station II in January 2009 and 31 birds at station III in December 2009.

\section{Kentish Plover Charadrius alexandrinus}

The Kentish Plover was recorded in small numbers in all three stations. The highest count was 18 birds in station I (January 2009) and II (December 2008) and 11 birds in station III (January 2009).

\section{Lesser Sand Plover Charadrius mongolus}

This is a common winter migrant species and most of the sightings were recorded from December to February with small flocks. The highest count was 33 birds in station I in December 2007, 17 birds in station II in December 2008 and 25 birds in station III in December 2009.

\section{Black-tailed Godwit Limosa limosa}

The Black-tailed Godwit was a common regular winter migrant to the Point Calimere. Large flocks of 96, 61 and 50 birds were seen during January 2009 at stations I, II and III respectively.

\section{Bar-tailed Godwit Limosa lapponica}

The Bar-tailed Godwit wad also a common regular winter migrant to the Point Calimere Wildlife. The high counts include 89 birds in January 2009 in station I, 52 birds in December 2008 in station II and 42 birds in December January 2009 at station III.

\section{Whimbrel Numenius phaeopus}

This species is very rare winter migrant to the study area. One group of four individuals was seen during January 2009 at station I and no birds have been recorded at stations II and III.

\section{Eurasian Curlew Numenius arquata}

This species was seen rarely, usually occurring in small parties of twos and threes. A high count of 6 birds was sighted in station I during January 2009, 3 birds was sighted in station II during December 2009 and 9 birds was sighted in station III during January 2010.

\section{Common Redshank Tringa totamus}

It is one of the commonest winter migrant sandpipers in 
Point Calimere Wildlife Sanctuary, usually occurring in small flocks. The highest count of a congregation was 32 birds in January 2009 at station I, 18 birds in January 2010 at station II and 13 birds in December 2008 at station III.

\section{Marsh Sandpiper Tringa stagnatilis}

This species was recorded occasionally in compact flocks of a few birds and the highest count was 19 birds during January 2009 in station I, 11 birds during January 2008 at station II and 11 birds during December 2009 at station III.

\section{Common Greenshank Tringa nebularia}

It is a rare winter migrant species to Point Calimere Wildlife Sanctuary, usually occurring in small flocks. The maximum count obtained during this study was 16 birds in January 2008 at station I and 8 birds in December 2009 at station II and no birds were observed at station III.

\section{Terek Sandpiper Xenus cinereus}

This species was seen very rarely, with records in December and January, indicating that is winter migrant. A maximum count of 6 birds was sighted in station I during January 2009, 4 birds was sighted in station II during January 2008 and 6 birds were sighted in station III during December 2009.

\section{Common Sandpiper Actitis hypoleucos}

The Common Sandpiper was very rare to Point Calimere, recorded only few numbers. During this study, with the highest count were 6 birds at station I during January 2008, 4 birds at station II during December 2008 and 9 birds at station III during January 2010.

\section{Curlew Sandpiper Calidris ferruginea}

This species is a common winter migrant with largest congregation of 88 birds in station I during December 2009, 39 birds in station II during January 2008 and 41 birds in station III during January 2010.

\section{Ruddy Turnstone Arenaria interpres}

The Ruddy Turnstone is a very rare winter migrant to the study area. Nine birds were recorded during January 2009 in station I and 4 birds were recorded during December 2009 in station II and no birds were recorded in station III.

\section{Little Stint Calidris minuta}

This species is very common, most abundant winter migrant and large flocks were usually seen during December January. In station I, a flock of 274 birds was recorded during January 2009, in station II, 154 birds was recorded during January 2010 and station III, 165 birds were recorded during December 2008.

\section{Black-winged Stilt Himantopus himantopus}

This is a very rare winter migrant species occurring in very few flocks in study area. In station I, maximum of 9 birds was sighted in November 2009, in station II, 6 birds were sighted in January 2009 and in station III, 8 birds were sighted in January 2008.

\section{Red-wattled Lapwing Vanellus indicus}

The Red-wattled Lapwing is a common species in freshwater habitats but rarely occurred in the study area. The bird recorded only at station I with a highest count of 4 birds in January 2009.

\section{Small waders' density and diversity}

The multiple regression equation models developed to predict the influence of physico-chemical parameters of water and prey availability on waders' density and diversity in the study area.

The calcium, dissolved solids, electrical conductivity, nitrate, $\mathrm{pH}$, salinity, turbidity, water depth, water temperature, phytoplankton abundance, polycheates number and amphipods number were significantly influencing the density of small waders which explained $50.8 \%$ of total variance (Table 1). The calcium, chloride, dissolved oxygen, magnesium, $\mathrm{pH}$, phosphate, salinity, turbidity, water depth, phytoplankton abundance, zooplankton abundance and polycheates number were significantly influencing the diversity of small waders which explained $38.5 \%$ of total variance (Table 1 ).

\section{Large waders' density and diversity}

The large waders' density was best predicted by calcium, electrical conductivity, nitrate, nitrite, phosphate, salinity, sulphate, turbidity, water depth, phytoplankton abundance, polycheates density, gastropods density and decapods density. The above parameters accounted for $52.7 \%$ of total variance (Table 2). The calcium content, dissolved solids, electrical conductivity, nitrite, $\mathrm{pH}$, salinity, total dissolved solids, turbidity, water depth, phytoplankton abundance, zooplankton abundance, polycheates density and Gastropods density were significantly influencing the diversity of large waders which explained $42.2 \%$ of total variance (Table 2 ).

\section{Discussion}

Most of the waders and other waterbirds inhibit the GVS as their winter home. Every year from October onwards a considerable number of waterbirds reach this wetland. The peak winter population of the waders was seen during December - January. Unfortunately, when compared to previous reports, the waterbirds richness and abundance was seriously declined due to various ecological and anthropogenic pressures in the study area. According to Nagarajan and Thiyagesan[6], the Greater Flamingo Phoenicopterus ruber population which usually consisted of around 20,000 individuals declined from 3,351 in 1986 to 1,254 in the present study. Balachandran[16] stated that until the 1990s, Point Calimere was the most important site for waders, supporting hundreds of thousands of birds throughout the migration season and now degraded as a result of human interferences, and a decline of over $70 \%$ has been noted in the wader populations. In the 1980 s, the Point Calimere supported $>10,000$ Lesser Sand Plover, $>15,000$ Blackwinged Stilt, >50,000 Black-tailed Godwit, >200,000 Little Stint and $>150,000$ Curlew Sandpipers[16], but these have now become scarce $(<500$ during the present study period, 
2007-2010). Compared to previous reports from Tamil Nadu Forest Department Census Records (unpubl. data), the abundance of many waterbird species are now becoming very rare and uncommon and declining year after year. A considerable number of Pied Avocets Recurvirostra avosetta, Crab Plover Dromas ardeola, Eurasian Oystercatcher Haematopus ostralegus, Sanderling Calidris alba, Spotted Redshank Tringa erythropus, Ruff Philomachus pugnax, Pacific Reef Egret Egretta sacra, Pacific Golden Plover Pluvialis fulva and River Tern Sterna aurantia were reported earlier, but have not been sighted since 2007.

Studies on the effects of bird aggregation on the physico-chemical conditions of water and vice versa have been made by several authors[17-21]. The area of open water is an important factor determining bird congregation[4], while aggregations of migratory birds in smaller bodies of water significantly change the water quality by the addition of extra loads of nutrients[22]. Multiple regression analysis between the physico-chemical parameters of water and the waders' characteristics in the study area showed that salinity, $\mathrm{pH}$, water temperature, water depth, electrical conductivity, dissolved oxygen, turbidity, chloride, phosphate, sulphate, calcium and magnesium hardness, total dissolved solids and nitrate have significant differences with waders' density and diversity.

Water $\mathrm{pH}$ of the wetlands is reported to have a profound influence on the avian population characteristics. Schell and Krekes[23] stated that acidic wetlands are inferior waterfowl habitats, at least in the sense that they have less vegetation for shelter and substrate for invertebrates. Since $\mathrm{pH}$ may be considered an indicator of overall productivity that can cause habitat diversity[24]. A significant relationship between waders' diversity and $\mathrm{pH}$ of the wetland habitats was established by Nagarajan and Thiyagesan[6], Pandiyan[18] and Sonal et al.[25].

Table 1. Multiple regression equation models to investigate the influence of physico-chemical parameters of water and prey availability on the density and diversity of small waders in the study area, 2007-2010

\begin{tabular}{|c|c|c|c|c|c|c|c|}
\hline $\begin{array}{c}\text { Dependant } \\
\text { variables }\end{array}$ & Predictor variables & Coefficient & SE Coefficient & $t$ & $P$ & Model $F \& P$ & $R^{2}$ \\
\hline $\begin{array}{l}\text { DENSITY OF } \\
\text { SMALL } \\
\text { WADERS }\end{array}$ & $\begin{array}{l}\text { Constant } \\
\text { Calcium } \text { Calcium }^{2} \\
\text { Dissolved solids } \\
\text { Electrical conductivity } \\
\text { Nitrate } \\
\text { Nitrate }^{2} \\
\text { Nitrate }^{3} \\
\mathrm{pH} \\
\mathrm{pH}^{2} \\
\text { Salinity }^{2} \\
\text { Turbidity } \\
\text { Water depth } \\
\text { Water depth } \\
\text { Water temperature } \\
\text { Phytoplankton abundance } \\
\text { Phytoplankton abundance } \\
\text { Polycheates number } \\
\text { Amphipods number }\end{array}$ & $\begin{array}{c}-0.3721 \\
0.034011 \\
-0.0001657 \\
-0.003425 \\
0.8851 \\
-0.01238 \\
0.004534 \\
0.24171 \\
0.01852 \\
-0.0178223 \\
-0.88253 \\
0.05647 \\
1.5587 \\
0.5983 \\
-2.434054 \\
-0.22254 \\
0.15321 \\
0.01853210 \\
-0.005023\end{array}$ & $\begin{array}{c}0.1725 \\
0.001254 \\
0.00414 \\
0.000152 \\
0.2478 \\
0.01073 \\
0.01588 \\
0.66311 \\
0.002317 \\
0.0075470 \\
0.22541 \\
0.008945 \\
0.5521 \\
1.118 \\
0.0468448 \\
0.05621 \\
0.05423 \\
0.0002355 \\
0.001250\end{array}$ & $\begin{array}{l}-2.36 \\
3.47 \\
-5.87 \\
-3.16 \\
3.20 \\
-4.15 \\
2.56 \\
9.31 \\
4.95 \\
-3.41 \\
-5.57 \\
3.39 \\
4.20 \\
2.18 \\
-4.16 \\
-5.30 \\
3.65 \\
2.64 \\
-2.96\end{array}$ & $\begin{array}{l}0.020 \\
0.001 \\
0.000 \\
0.002 \\
0.002 \\
0.000 \\
0.011 \\
0.000 \\
0.001 \\
0.001 \\
0.000 \\
0.001 \\
0.001 \\
0.030 \\
0.001 \\
0.000 \\
0.002 \\
0.023 \\
0.015\end{array}$ & $\begin{array}{l}28.36 \\
0.000\end{array}$ & $50.8 \%$ \\
\hline $\begin{array}{c}\text { DIVERSITY OF } \\
\text { SMALL } \\
\text { WADERS }\end{array}$ & $\begin{array}{l}\text { Constant } \\
\text { Calcium } \\
\text { Chloride } \\
\text { Dissolved oxygen } \\
\text { Dissolved oxygen }^{2} \\
\text { Magnesium }^{2} \\
\text { Magnesium } \\
\text { pH } \\
\text { Phosphate Phosphate } \\
\text { Salinity } \\
\text { Salinity }^{2} \\
\text { Salinity }^{3} \\
\text { Turbidity } \\
\text { Water depth } \\
\text { Phytoplankton abundance } \\
\text { Zooplankton abundance } \\
\text { Polycheates number } \\
\text { Polycheates number } \\
\text { Poly }\end{array}$ & $\begin{array}{c}0.35321 \\
-0.000015863 \\
0.0026452 \\
-0.12030 \\
-0.0000254 \\
-0.4597 \\
-0.01785 \\
0.188723 \\
-0.26236 \\
-0.040457899 \\
0.555478 \\
0.0061447 \\
-0.0578754 \\
-2.036 \\
0.001365 \\
-0.013195 \\
0.01136895 \\
-0.000152654\end{array}$ & $\begin{array}{c}0.062958 \\
0.00008565 \\
0.00085 \\
0.03762 \\
0.000009872 \\
0.5515 \\
0.006578 \\
0.001854 \\
0.07654 \\
0.0157879 \\
0.009875 \\
0.00235589 \\
0.004721 \\
1.908 \\
0.02544 \\
0.002541 \\
0.00284256 \\
0.000006521\end{array}$ & $\begin{array}{c}6.21 \\
-5.20 \\
4.87 \\
-3.20 \\
-2.55 \\
-6.83 \\
-2.74 \\
8.65 \\
-3.24 \\
-2.56 \\
5.47 \\
2.38 \\
-3.62 \\
-2.50 \\
5.48 \\
-4.20 \\
4.08 \\
2.36\end{array}$ & $\begin{array}{l}0.000 \\
0.000 \\
0.002 \\
0.002 \\
0.011 \\
0.000 \\
0.006 \\
0.000 \\
0.001 \\
0.014 \\
0.000 \\
0.024 \\
0.001 \\
0.003 \\
0.000 \\
0.000 \\
0.000 \\
0.025\end{array}$ & $\begin{array}{l}23.20 \\
0.000\end{array}$ & $38.5 \%$ \\
\hline
\end{tabular}


Table 2. Multiple regression equation models to investigate the influence of physico-chemical parameters of water and prey availability on the density and diversity of large waders in the study area, 2007-2010

\begin{tabular}{|c|c|c|c|c|c|c|c|}
\hline $\begin{array}{c}\text { Dependant } \\
\text { variables }\end{array}$ & Predictor variables & Coefficient & SE Coefficient & $\mathbf{t}$ & $\mathbf{P}$ & Model $F \& P$ & $R^{2}$ \\
\hline $\begin{array}{l}\text { DENSITY OF } \\
\text { LARGE } \\
\text { WADERS }\end{array}$ & $\begin{array}{l}\text { Constant } \\
\text { Calcium }^{2} \\
\text { Calcium }^{2} \\
\text { Electrical conductivity } \\
\text { Nitrate } \\
\text { Nitrite } \\
\text { Phosphate } \\
\text { Salinity } \\
\text { Sulphate } \\
\text { Sulphate } \\
\text { Turbidity } \\
\text { Turbidity } \\
\text { Water depth } \\
\text { Phytoplankton abundance } \\
\text { Polychaetes density } \\
\text { Polychaetes density } \\
\text { Gastropods density } \\
\text { Decapods density }\end{array}$ & $\begin{array}{c}0.88421 \\
-0.6828 \\
0.0336977 \\
-0.013919 \\
-1.549 \\
-0.019410 \\
-0.05301 \\
0.02997 \\
0.003551 \\
-0.00008874 \\
-0.000010005 \\
0.0000061 \\
0.11581 \\
0.00008312 \\
0.034021 \\
-0.00312100 \\
1.2295 \\
-0.011032\end{array}$ & $\begin{array}{c}0.054183 \\
0.6406 \\
0.1945413 \\
0.004138 \\
0.09401 \\
0.8955 \\
0.01449 \\
0.010247 \\
0.001658 \\
0.00003547 \\
0.00003258 \\
0.0000032 \\
0.3847 \\
0.00003410 \\
0.05321 \\
0.00011423 \\
0.4215 \\
0.003124\end{array}$ & $\begin{array}{c}8.65 \\
-4.07 \\
11.77 \\
-3.39 \\
-5.49 \\
-2.86 \\
-3.74 \\
3.65 \\
4.85 \\
-3.25 \\
-6.33 \\
6.07 \\
4.10 \\
3.78 \\
6.05 \\
-3.16 \\
3.55 \\
-3.24 \\
\end{array}$ & $\begin{array}{l}0.000 \\
0.000 \\
0.000 \\
0.002 \\
0.000 \\
0.015 \\
0.001 \\
0.002 \\
0.000 \\
0.002 \\
0.000 \\
0.000 \\
0.000 \\
0.000 \\
0.000 \\
0.004 \\
0.002 \\
0.003\end{array}$ & $\begin{array}{l}22.36 \\
0.000\end{array}$ & $2.7 \%$ \\
\hline $\begin{array}{c}\text { DIVERSITY OF } \\
\text { LARGE } \\
\text { WADERS }\end{array}$ & $\begin{array}{l}\text { Constant } \\
\text { Calcium } \\
\text { Dissolved solids } \\
\text { Electrical conductivity } \\
\text { Nitrite } \\
\mathrm{pH} \\
\mathrm{pH}^{2} \\
\mathrm{pH}^{3} \\
\text { Salinity } \\
\text { Total dissolved solids } \\
\text { Turbidity } \\
\text { Water depth } \\
\text { Water depth } \\
\text { Phytoplankton abundance } \\
\text { Zooplankton abundance } \\
\text { Zooplankton abundance } \\
\text { Polychaetes density } \\
\text { Gastropods density }\end{array}$ & $\begin{array}{c}-0.3762 \\
0.008102 \\
0.09018 \\
-0.013919 \\
-0.05684 \\
-0.00000001 \\
0.00000000 \\
0.035894 \\
0.002474 \\
0.210841 \\
-0.006521 \\
-0.21236 \\
0.01147 \\
0.0294210 \\
0.05425 \\
-0.00072410 \\
0.05621 \\
-0.0152331\end{array}$ & $\begin{array}{c}0.16875 \\
0.003557 \\
0.03659 \\
0.004138 \\
0.05826 \\
0.00000000 \\
0.00000000 \\
0.006877 \\
0.001425 \\
0.08478 \\
0.002574 \\
0.08872 \\
0.00563 \\
0.0041251 \\
0.01241 \\
0.00043611 \\
0.00942 \\
0.052141\end{array}$ & $\begin{array}{c}-6.21 \\
4.28 \\
4.41 \\
-3.63 \\
-3.98 \\
3.14 \\
3.69 \\
6.21 \\
8.41 \\
5.48 \\
-4.38 \\
-5.12 \\
3.36 \\
4.11 \\
5.79 \\
-4.44 \\
5.86 \\
-3.35\end{array}$ & $\begin{array}{l}0.000 \\
0.000 \\
0.000 \\
0.002 \\
0.000 \\
0.003 \\
0.003 \\
0.000 \\
0.000 \\
0.000 \\
0.000 \\
0.000 \\
0.003 \\
0.000 \\
0.000 \\
0.000 \\
0.000 \\
0.002\end{array}$ & $\begin{array}{l}13.65 \\
0.000\end{array}$ & $42.2 \%$ \\
\hline
\end{tabular}

Salinity had been reported to influence to a large extent the succession and dominance of various aquatic organisms. Diatoms were found to be high in the North Kanara coast when the salinity was low[26]. The invertebrate diversity decreased dramatically in the 40-70 ppt salinity range and remained at that level until about $100 \mathrm{ppt}$ in the areas of salt works in France[27]. Furthermore, higher salinities were reported to cause reduction in the prawn and fish diversity and abundance as well[27]. Espino-Barros and Baldassarre[28] investigated the habitat utilization of flamingo and found that the salinity within the three manmade habitats ranged from $80 \mathrm{ppt}$ (low saline salt ponds) to $206 \mathrm{ppt}$ (high saline canal); however, flamingos avoid ponds (crystallizers) where salinity readings exceeded $206 \mathrm{ppt}$. Interestingly, Baldassarre and Arengo[29] found that most food was found in the low-salinity ponds (63-73 ppt) and high salinity ponds (147-205 ppt); no food was found in intermediate salinity ponds $(78-136 \mathrm{ppt})$. In the study area the salinity ranged from 8 to $61 \mathrm{ppt}$. The multiple regression analysis inferred that the salinity is the prime factor that determined the quality of the foraging habitats of the both small and large waders. The changes in the salinity would have influenced the diversity and abundance of the aquatic organisms which were the major food sources for waders.

Lelek[30] has reported that wader densities are influenced by dissolved oxygen in the wetlands and similar observation by Sampath and Krishnamurthy[31] at Kaliveli tank, Tamil Nadu and Sonal et al.[25] at a village pond of Masar village, Gujarat, India. Electrical conductivity is a measure of the ionic composition of the medium and as such it plays a vital role in the release of the nutrients as well their uptake by the plants. Nagarajan[32] and Pandiyan[18] have opined that electrical conductivity would have significance on the waders' population structure in Tamil Nadu, India. Turbidity and total dissolved solids, which can influence the productivity in an aquatic ecosystem, are found to influence the waders' habitat selection. Pandiyan[18] stated that turbidity levels play an important role in determining the waders' diversity in the tidal flats. As such this kind of influence by these factors would have yielded the positive relationship observed 
to this present study.

The present study inferred that levels of nutrients such nitrates, nitrites, phosphates and sulphates are the other factors that probably play a major role in determining the waders' population in the study area. A study of waterbird habitat relationship on lake in Sweden by Nilson and Nilson[33] yielded that total phosphorous is the best predictor of waders' density. Nagarajan and Thiyagesan[6] and Pandiyan[18] concluded that the physico-chemical parameters of water largely determined the waders' community of wetland habitats primarily by their direct and indirect impacts on the role of food availability and abundance on the birds of prey. Similar trend is true of the GVS of the Point Calimere Wildlife Sanctuary as evidenced by the data generate herein.

Water depth has been reported to be an important factor affecting the distribution and density of waders[6]. Role of water depths in the wetland use by water birds had also been documented by Rostogi and Pathak[34] for cormorants and coots. Sridharan[35] found significant correlation between the population of resident ducks and water depth in Keoladeo National Park, Bharatpur, India. Taylor et al.[36] found that there was a great variation in numbers of shore birds on wet mud flats from week to week and from year to year, and at least some of this variation was caused by water level fluctuations and mudflats exposure timing. In the present study the water depth of the swamp between 20 and $34 \mathrm{~cm}$. The multiple regression analysis of the present study inferred that water depth appears to be the main factor for the habitat preferences of the waders in Point Calimere Wildlife Sanctuary.

The GVS of the Point Calimere Wildlife Sanctuary owing its peculiar fresh, brackish or saline water characteristics harbours a rich planktonic abundance and benthic invertebrate community viz., polycheates, molluscs, crustaceans, nematodes and insects. This wide variety planktonic and invertebrate community in turn harboured a rich community of waders, ducks, gulls and terns. The high productivity of the silty-sand and loosely made sandy sediment made the benthic invertebrates easily accessible for waders[37]. The waders used this wetland as staging site in monsoon (October-December) indicating that the wetland serve as important stopover point for waders migrating along the Central Asian Indian migratory flyway.

The migratory waterbirds are known to feed on a high protein diet on their wintering grounds[38], thus the GVS serve as important foraging grounds to waders, provide adequate food supply. The multiple regression analysis also confirmed that occurrence of polycheates, gastropods, decapods, amphipods and phyto and zoo planktons were significantly influenced the density and diversity of waders' in the study area. Food density has been used by many authors to explain differential habitat use by waterbirds at migratory stop over sites[18,39-42]. According to Safran et al.[43], the ecology of waterbirds are closely related to the distribution and abundance of food resources and for many species of waterbirds benthic invertebrates are important dietary components that influence habitat selection. The polycheates and other food sources to waders in the study area are indicating that prey is a vital factor that attracts waders to habitat.

\section{Conclusions}

The present study suggests the GVS of the Point Calimere Wildlife Sanctuary to be the important feeding grounds for the migratory and the resident species of the waterbirds. Various abiotic parameters and prey resources plays important role to determine the density and diversity 30 small and large waders. The above information will be useful for the preparation of a management plan for ornithologists and for conservation. The GVS of the Point Calimere Wildlife Sanctuary is under great pressure on account of many threats which have led to shrinking of swamps and their biological resource potential. The main threats were hunting or poaching, increased salinity due to salt production and human disturbances. There is an immediate need to restore and conserve this existing wetland to maintain and improve the ecological balance.

\section{ACKNOWLEDGEMENTS}

We thank the Department of Forests, Nagapattinam and Chief Conservator of Forests for permitting to collect data in the sanctuary and for their support and help. Authors are grateful to the Management, the Principal and the HOD of Zoology, A.V.C. College (Autonomous), Mannampandal, India for providing necessary facilities.

\section{REFERENCES}

[1] Paracuellos, M., 2006, How can habitat selection affect the use of a wetland complex by waterbirds? Biodiversity and Conservation, 15: 4569-4582

[2] Jaksic, F., 2004, El Niño effects on avian ecology: lesson learned from the southeastern Pacific. Ornitologia Neotropical, 15: 61-72

[3] Lagos, N.A., Paolini, P., Jaramillo, E., Lovengreen, C., Duarte, C., and Contreras, H., 2008, Environmental processes, water quality degradation, and decline of waterbird populations in the Rio cruces wetland, Chile. Wetlands, 28: 938-950

[4] Patterson, J.H., 1976, The role of environmental heterogeneity in the regulation of duck populations. Journal of Wildlife Management, 40: 22-32

[5] Murphy, S.M., Kessel, B., and Vining, L.J., 1984, Waterfowl populations and limnological characteristics of Taiga Ponds. Journal of Wildlife Management, 48: 1156-1163

[6] Nagarajan, R., and Thiyagesan, K., 1996, Waterbirds and substrate quality of the Pichavaram wetlands, southern India. Ibis, 138: 710-721

[7] Takekawa, J.Y., Miles, A.K., Schoellhamer, D.H., Athearn, 
N.D., Saiki, M.K., Duffy, W.D., Kleinschmidt, S., Shellenbarger, G.G., and Jannusch, C.A., 2006, Trophic structure and avian communities across a salinity gradient in evaporation ponds of the San Francisco Bay estuary. Hydrobiologia, 567: 307-327

[8] Wetzel, R.G., 1975, Limnology. W.B. Saunders Company, Philadelphia

[9] Nagarajan, R., Lea, S.E.G., and Goss-Custard, J.D., 2006, Seasonal variations in mussel, Mytillus edulis L. shell thickness and strength and their ecological implications. Journal of Experimental Marine Biology and Ecology, 339: 241-250

[10] Rundle, W.D., 1982, A case for esophageal analysis in shorebird food studies. Journal of Field Ornithology, 55: 249-257

[11] Bolduc, F., and Afton, A.D., 2008, Monitoring waterbird abundance in wetlands: The importance of controlling results for variation in water depth. Ecological Modelling, 216: $402-408$

[12] Ali, S., 1969, The Book of Indian Birds (8th edition). Bombay Natural History Society, Bombay, India

[13] King, B., Woodcock, M., and Disckinson, E.C., 1978, A field guide to the birds of South-east Asia. Collins, St. Jame's Palace, London

[14] Sonobe, K., and Usui, S, (Eds.), 1993, A field guide to the water birds of Asia. Wildlife Bird Society of Japan, Tokyo

[15] Grimmett, R., Inskipp, C., and Inskipp, T., 2001, Birds of the Indian Subcontinent. (Revised reprint 2001), Christopher Helm, London

[16] Balachandran, S., 2006, The decline in wader populations along the east coast of India with special reference to Point Calimere, south-east India. Waterbirds around the world. Boere, G.C., C.A. Galbraith and D.A. Stroud (Eds.). The Stationery Office, Edinburgh, UK. pp. 296-301

[17] Manny, B.A., Johnson, W.C., and Wetzel, R.G., 1994, Nutrient additions by waterfowl to lakes and reservoirs: predicting their effects on productivity and water quality. Hydrobiologia, 279/280: 121-132

[18] Pandiyan, J., 2002, Ecology of shorebirds in the tidal flats of Cauvery deltaic region of Southern India. Ph.D. Thesis, Bharathidasan University, Thiruchirappalli, India

[19] Hanson, A.R., 2003, Chemical limnology and waterbird community of an urban constructed wetland. In: Proceedings of the $4^{\text {th }}$ Conference: Aquatic Birds Working Group of Societas Internationalis Limnologiae (SIL), Sackville, Canada. pp. 26

[20] Longcore, J.R., McAuley, D.G., Pendelton, G.W., Bennatti, C.R., Mingo, T.M., Stromborg, K.L., 2006, Macroinvertebrate abundance, water chemistry, and wetland characteristics affect use of wetlands by avian species in Maine. Hydrobiologia, 567: 143-167

[21] Unckless, R.L., and Makarewicz, J.C., 2007, The impact of nutrient loading from Canada Geese (Branta canadensis) on water quality, a mesocosm approach. Hydrobiologia, 586: 393-401

[22] Andrikovics, S., Gare, G., Juhasz, J., and Lakatos, G., 2003, Mallard population parameters and their effect on water quality. In: Proceedings of the $4^{\text {th }}$ Conference: Aquatic Birds
Working Group of Societas Internationalis Limnologiae (SIL), Sackville, Canada. pp. 15-16

[23] Schell, D., and Krekes, J.J., 1989, Distribution, abundance and biomass of benthic macro invertebrates in relation to $\mathrm{pH}$ and nutrients in 8 lakes, Nova Scotia, Canada. Water, Air, Soil and Pollution, 46: 354-374

[24] Minns, C.K., 1989, Factors affecting fish species richness in Ontario lakes. Trans. American Fish Society, 118: 533-545

[25] Sonal, D., Jagruti, R., and Geeta, P., 2010, Avifaunal diversity and water quality analysis of an inland wetland. Journal of Wetlands Ecology, 4: 1-32

[26] Ramamurthy, S., 1965, Studies on the plankton of the North Kanara coast in relation to the pelagic fishery. Journal of Marine Biology Association India, 7: 127-149

[27] Ramachandran, P.V., Lulter, G., and Adolph, C., 1965, An ecological study of some pools near Mandabam (South India) formed as a result of the cyclone and tidal wave of 1964. Journal of Marine Biology Association India, 7: 420-439

[28] Espino-Barros, R., and Baldassarre, G.A., 1989, Activity and habitat-use patterns of breeding Caribbean Flamingos in Yucatan, Mexico. Condor, 91: 585-591

[29] Baldassarre, G.A., and Arengo, F., 2000, A review of the ecology and conservation of Caribbean Flamingos in Yucaton, Mexico. Waterbirds, 23: 70-79

[30] Lelek, A., 1988, Preservation and re naturalization of dead channels with some examples of Rhine area. Arb. Disch. Fish. Verb., 46: 98-103

[31] Sampath, K., and Krishnamurthy, K., 1990, Shorebirds (Charadriiformes) of the Pichavaram mangroves, Tamil Nadu, India. Wader Study Group Bulletin, 58: 24-27

[32] Nagarajan, R., 1990, Factors Influencing Wader (Ciconiiformes and Charadriiformes) Populations in the Wetlands of Pichavaram, Tamil Nadu, South India. M.Phil. Thesis, Bharathidasan University, Thiruchirappalli, India

[33] Nilson, S.G., and Nilsson, O.N., 1978, Breeding bird community densities and species richness in lakes. Oikos, 31: 214-221

[34] Rostogi, V.S., and Pathak, A.K., 1990, Wintering waterfowl in upper lake of Bopal. In: Proc. Seminar on Wetland Ecology and Management; 1990 February 23-25; Keoladeo National Park, Bharatpur, Bombay Natural History Society, Bombay. P. 9

[35] Sridharan, V., 1989, Comparative ecology of resident ducks in Keoladeo National Park, Bharatpur, Rajasthan. Ph.D. Thesis, University of Bombay, Bombay

[36] Taylor, D.M., Trost, C.H., and Jamison, B., 1992, Abundance and chronology of migrant shorebirds in Idaho. Western Birds, 23: $49-78$

[37] Borges, S.D., 2002, Studies on the ecology of wader birds in the Mandovi estuary of Goa, India. Ph.D. Thesis, Goa University, Goa

[38] Halse, S.A., Shiel, R., and Pearson, G.B., 1996, Waterbirds and aquatic invertebrates of swamps on the Victoria-Bonaparte mudflat, north Western Australia. Journal of Royal Society of Western Australia, 79: 217-224 
[39] Tsipoura, N., and Burger, J., 1999, Shorebird diet during spring migration stopover on Delaware Bay. Condor, 101: 635-644

[40] Gill, J.A., Sutherland, W.J., and Norris, K., 2001, Depletion models can predict shorebird distribution at different spatial scales. Proceedings of the Royal Society of London, 268: 369-376

[41] Pomeroy, A., and Butler, R.W., 2005, Color infrared photography is not a good predictor of macro invertebrate Abundance on Mudflats Used by Shorebirds. Waterbirds, 28(1):
$1-7$

[42] Mendonca, V.M., Raffaelli, D.G., and Boyle, P.R., 2007, Interactions between shorebirds and benthic invertebrates at Culbin Sands lagoon, NE Scotland: Effects of avian predation on their prey community density and structure. SCI. MAR., 71(3): 579-591

[43] Safran, R.J., Isola, C.R., Colwell, M.A., and Williams, O.E., 1997, Benthic invertebrates at feeding locations of nine waterbird species in managed wetlands of the northern San Joaquin Valley, California. Wetlands, 17: 407-415 